\title{
CREATIVE COMPETENCE IN BORROWINGS: WORDS OF JAPANESE ORIGIN IN SLOVENE
}

\section{INTRODUCTION}

'Karaoke'1, 'anime'2, 'shiitake'3. These are words of Japanese origin borrowed in many European languages today. In the case of English (or even German, French etc.) these words basically retain their original appearance, as they are employed in the context in the recipient language, since the recipient language has no noun inflection. In case of Slovene, it is different. Here are some published examples of these words in context ${ }^{4}$ :

(1) Je že res, da živimo v dobi karaok, ... [Dnevnik 2005-03-04]

"It's true that we live in the karaoke era, ..."

(2) Kot sem rekel: mange bere staro in mlado. Isto velja za gledanje animejev.

[Joker 2006-08-01]

"As I said: mangas are read by old and young. The same holds true for watching animes."

(3) 5 šitakov [Svet in ljudje 2004-02]

"5 shiitakes" (in a recipe)

Though the original forms of these loanwords all end in the same vowel $-e$ and all are used in the Slovene sentences in the genitive case, 'karaoke' is used in sentence (1) in the feminine plural, 'anime' in sentence (2) in the masculine plural, and 'shi-

\footnotetext{
* Author's address: Filozofska fakulteta, Oddelek za azijske in afriške študije, Aškerčeva 2, 1000 Ljubljana, Slovenia. Email: chikako.bucar@guest.arnes.si

1 [mass noun] a form of entertainment, offered typically by bars and clubs, in which people take turns to sing popular songs into a microphone over pre-recorded backing tracks. - ORIGIN 1970s: from Japanese, literally 'empty orchestra'. (Oxford Dictionary of English 2003)

2 [mass noun] Japanese film and television animation, typically having a science-fiction theme and sometimes including violent or explicitly sexual material. - ORIGIN 1980s: Japanese. (Oxford Dictionary of English 2003)

3 (also shitake, shiitake mushroom) an edible mushroom which grows on fallen timber, cultivated in Japan and China. Lentinus edodes, family Pleurotaceae, class Hymenomycetes. - ORIGIN late $19^{\text {th }}$ cent.: from Japanese, from shii, denoting a kind of oak, + take 'mushroom'. (Oxford Dictionary of English 2003)

${ }^{4}$ Example sentences are taken from Fidaplus, the Slovene referential corpus. In the square bracket are the source (periodicals) and the date of appearance as indicated in the corpus.
} 
itake (šitake)' in sentence (3) in the masculine singular. If we try to trace these words back to the form of nominative and genitive singular in Slovene which is usually used for dictionary entries, they would be: karaoka -e; anime -ja; and šitak -i. ${ }^{5}$

There are several reasons and different motivations for the assignment of number and gender to loanwords before users of the recipient language arrive at agreement for certain linguistic rules. In the following sections, the grammatical characteristics of the source language (Japanese) and the recipient language (Slovene) in relation to the process of borrowing are reviewed (sections 2 and 3), and possible rules of gender and number assignment to loanwords of Japanese origin are given (section 4). The degree of integration into the recipient language for the loanwords is further verified through derivation of new words (section 5). Based on the findings in the case of borrowings of Japanese origin into Slovene, the creative competence of speakers is discussed.

\section{JAPANESE}

\subsection{Noun morphology}

Japanese has no category of number or of gender. Nouns may be used to denote singular or plural in one and the same form according to context. In addition, Japanese nouns (as well as adjectives) have no case inflection, but the syntactic relationships to verbs are expressed by the use of postpositional case particles. These characteristics may be observed in the following example sentences:

$\begin{array}{llllll}\text { (4) } \begin{array}{llll}\text { Kinoo } \\ \text { yesterday } \\ \text { "I bought a cookbook yesterday." }\end{array} & \begin{array}{l}\text { ryoori } \\ \text { cooking }\end{array} & \text { GEN } & \underline{\text { hon }} & \text { wo } & \text { katta. } \\ \text { buy-PAST }\end{array}$ "I put the books in the library in order yesterday."

The noun hon, 'book', appears in both sentences in the same form, but it is translated as "one book" in example (4) and plural "books" in example (5). Of course, sentence (4) may also mean "I bought cookbooks yesterday.", if the speaker loves cooking and often buys cookbooks. In the case of example (5), the noun hon is difficult to understand as a singular "book", since there are always many books in any library.

The voice relationship of the noun to the verb is expressed by the postpositional case particle, in the above cases wo to denote the accusative (or the direct object) case. The same noun may be accompanied by some other case particle, as in the following examples, and the form of the noun remains unchanged.

5 The dictionary entries for the Slovene language is usually given in the order of nominative singular genitive singular, e.g. lipa -e 'linden' (feminine), kot - $a$ 'corner' (masculine), mleko - a 'milk' (neuter). 


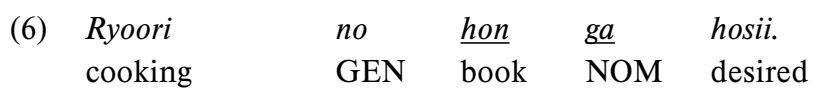

"I want a cookbook (I want cookbooks)."

(7) Ryoori no hon $\underline{\text { ni }}$ hana wo soete okutta.

cooking GEN book DAT flower ACC accompany-CONT send-PAST

"I added flowers to the cookbook and sent them."

"I sent a cookbook together with flowers."

\subsection{Phonology}

Phonologically speaking, Japanese is a syllabic language with basically open syllables which means that all syllables end in a vowel, with only two exceptions. Two kinds of moraic consonants $/ \mathrm{Q} /{ }^{6}$ and $/ \mathrm{N} /{ }^{7}$ may close a syllable, but within the Japanese phonological system, both are counted as mora-building. A mora is the standard rhythmic unit in Japanese. ${ }^{8}$ Theoretically, the structures of all possible morae in Japanese are: V, CV, Q, and N. Since the standard Japanese language has five vowels, a mora (and a syllable) of the type $\mathrm{V}$ or $\mathrm{CV}$ ends in one of the five vowels: $a, e, i, o$ or $u$. Regular Japanese nouns (and all other words) consist of one, two, three or more morae. For example, most simple nouns take the following form: te 'hand', ha 'tooth', asi 'foot', kutu 'shoe', atama 'head', otoko 'man'.

All five vowels in Japanese may be either short or long. Shibatani (1990) explains:

Long vowels contrast with short vowels, e.g. su 'vinegar': suu 'number', to 'door' : too 'ten'. A long vowel cannot simply be considered a single segment, for it is counted as two moras, and, furthermore, because pitch drop occurs in the middle of a long vowel, e.g. sūu (HL) 'number', just as in any two mora sequence, e.g. miso (HL) 'bean paste'. (Shibatani 1990: 161-162)

Another important phonological characteristic of Japanese is the accentual system, the so-called pitch accent. In modern standard Japanese, each mora is spoken

6 The phoneme /Q/ is a non-nasal consonant followed by a homorganic consonant of the following syllable, realized phonetically as a prolongation of consonantal articulation e.g. yappari /jaQpari/ [jappari] 'also', assari /aQsari/ [assari] 'plainly'. (Shibatani 1990: 158, 167-8) Both of the example words consist of 4-morae, since the mora-building $/ \mathrm{Q} /$ counts as one mora.

7 The phoneme /N/ is a nasal that closes a syllable, and unlike the non-nasal /Q/, it can end a word. In careful pronunciation it is close to the uvular nasal $[\mathrm{N}]$. In less careful speech it is realized as a nasalized version of the preceding vowel,e.g. hon /hoN/ [hõõ] 'book'. (Shibatani 1990: 169) Further examples: tonbo /toNbo/ [tombo] 'dragonfly'; ringo /riNgo/ [ringo] 'apple'; sandaru /saNdaru/ [sandaru] 'sandal(s)' (3, 3 and 4 morae, respectively)

${ }^{8}$ In Japanese phonology, a distinction needs to be made between suprasegmental units, syllable and mora. A word such as sinbun 'newspaper' consists of two syllables sin and bun, but a Japanese speaker further subdivides the word into the four units $s i, n, b u$, and $n$, which correspond to the four letters of kana used in the written form. A mora in Japanese is a unit that can be represented by one letter of kana and functions as a rhythmic unit in the composition of Japanese poems, e.g. waka and haiku. (Shibatani 1990: 158) 
approximately for the same length of time and carries a tone of either high $(\mathrm{H})$ or low (L). The pattern of high and low pitch is arbitrary and unpredictable, so they must be learned for each word. In the mainstream linguistic practice the last mora before a drop in pitch (the change in tone from high to low) is marked, for instance in dictionaries, as the accentual core of the word, e.g. $a^{r} t a^{7} m a$ (LHL), but this by all means cannot be compared with the system of stress accent. There are also many Japanese words of which several successive morae carry the high tone, even going over the word boundary, e.g. karate no sense' $i$ (LHH H HHHL) 'karate teacher'. The system of pitch accent, that is, a high or low tone carried by each of the rhythmic units of morae, and the opposition of long (two morae) and short (one mora) vowels are foreign to Slovene. These characteristics of Japanese phonology must be somehow modified or dropped when words of Japanese origin are imported for everyday use in Slovene.

\section{SLOVENE}

\subsection{Gender, number and case}

Slovene is a Slavic language and has three genders, i.e. masculine, feminine and neuter, as well as three numbers, i.e. singular, dual and plural. The nouns (and adjectives) are inflected in six cases: nominative, genitive, dative, accusative, instrumental, and locative. Because of case inflection, one word (a semantic entry in a dictionary) may appear in different forms in Slovene sentences. Consider the Slovene translations of the example sentences (4) to (7), from above:
(4') Včeraj
sem kupil
kuharsko
knjigo.
yesterday
AUX buy-PAST
cooking
book (acc. sg.)
"I bought a cookbook yesterday."
(5') Včeraj sem urejal yesterday AUX put in order-PAST
knjige $v$
knjižnici.
books (acc.pl.) in
library

"I put the books in the library in order yesterday."

(6') Želim

$\begin{array}{ll}\text { si } & \text { kuharsko } \\ \text { oneself } & \text { cooking }\end{array}$

knjigo.

wish-PRES

"I want a cookbook."

(7') Kuharski knjigi sem dodal rože in jih skupaj poslal. cooking book (dat. sg.) AUX add-PAST flowers and them together send-PAST "I added flowers to the cookbook and sent them."

Such alternation of vowels in a noun (knjiga - knjige - knjigi - ...) does not occur in Japanese. 


\subsection{Borrowings}

Toporišič (2000), in discussing the origins of various words in Slovene, defines prevzete besede 'assumed words/ borrowings' as all words taken from other languages into Slovene. Among common words of foreign origin a distinction is made between foreign words (tujke) and loanwords (izposojenke). While loanwords are those borrowings which have been thoroughly adapted to the Slovene language in their pronunciation, orthography, inflection, syntax and derivation of new words etc., foreign words have not completely adapted, especially in orthography, pronunciation, and inflection. (Toporišič 2000: 131).

About gender assignment of borrowings Priestly (1993) states:

[...] borrowed words normally become either masculine or feminine. The opposition between the two animacy subgenders - animate and inanimate - which is expressed in nouns and their co-referent adjectives and in some pronouns, occurs only in the singular. (Priestly 1993: 399)

Further, Priestly explains the incorporation of borrowings into the contemporary Slovene language as follows:

[...] we find that extremely few borrowed nouns are treated as indeclinables. Normally, if a borrowed noun ends in unstressed $-a$, it is feminine (declined as lipa) and otherwise the noun is masculine and declined as kòt. Note that nouns ending in - $r$ or a vowel add $-j-$ before non-zero endings, as in abonmâ, abonmâja 'subscription'. [...] Note also that virtually no recently borrowed nouns are neuter: hence nov kino 'new cinema', nov komite 'new committee', nov alibi 'new alibi', nov kanu 'new canoe'. (Priestly 1993: 444)

\section{ASSIGNMENT OF NUMBER AND GENDER}

\subsection{Morphological rules}

As we saw earlier, all Japanese nouns end in one of the five vowels, $a, e, i, o, u$, or in the syllable-closing, mora-building nasal, $-n$. As for the assignment of the grammatical category of number, it is expected that singular, the unmarked variant, is usually assigned to any noun. The category of gender, as we have already seen, should be decided according to the morphophonological form of the borrowed word. That is, nouns ending in the vowel $-a$ are categorized as feminine singular and inflected as feminine nouns. The inflection follows the pattern for many Slovene feminine nouns ending in $-a$, the first feminine declension, e.g. lipa $-e$. Japanese nouns which end in $-n$ as well as all other vowels, $e, i, o$ and $u$, should be considered masculine and declined accordingly: those that end in $-n$ are to be declined in the pattern used for many Slovene masculine nouns ending in a consonant, the first masculine declension, e.g. kot $-a$; those that end in vowels (and a stressed -a) would have extended inflection with the additional $-j$, as in the case of abonma above, or panó -ja "panneau (sign, notice in French)". 


\subsection{Semantics and language users' interpretation}

Added to the strictly morphophonological rules described in the previous section, some further rules that are otherwise valid for Slovene words also seem to apply to loanwords. Table 1 below shows all possible solutions for the assignment of number and gender to the loanwords of Japanese origin in Slovene. For all possible word endings in Japanese (listed in the far-left column), the solutions are given with examples.

The first solution (1) $(\langle 1\rangle,\langle 4\rangle,\langle 7\rangle,\langle 10\rangle,\langle 12\rangle,\langle 13\rangle)$ is given according to the morphological rules for loanwords in Slovene grammar, cited earlier from Priestly (1993) and regularly applied in Slovene.

The second solution (2) $(\langle 2\rangle,\langle 5\rangle,\langle 8\rangle)$ takes into account the possible interpretation of the original word ending as plural, especially when the object in question is countable and often used in context as plural, or the word is understood as a plural noun from the beginning. Examples of pluralia tantum in Slovene are: možgani -ov 'brain' (m.), vile vil 'fork' (f.), vrata vrat 'door' (n.). ${ }^{9}$ There are also several place names that are plural in Slovene, e.g. Jesenice Jesenic. Therefore, it is possible that Slovene speakers adopt a borrowed word as a plural noun when its meaning coincides with some plural connotation of countable objects, or the word is associated with some similar plural noun in Slovene. The plural interpretation may apply for the Japanese word endings $-a$, $-e$ and $-i$, neuter, feminine and masculine respectively.

In the column (3) $(\langle 3\rangle,\langle 6\rangle,\langle 9\rangle,\langle 11\rangle)$ are other possible solutions: application of other grammar rules for Slovene words, additional interpretation by language users etc.

Solutions in the table from $\langle 1\rangle$ to $\langle 13\rangle$ are explained below. Actual example sentences are taken from the referential corpus Fidaplus. Individual nouns are also verified in at least one of the existing dictionaries.

${ }^{9}$ Examples from Toporišič (2000: 271). 
Table 1: Gender and number assignments to borrowed nouns of Japanese origin in Slovene

\begin{tabular}{|c|c|c|c|c|c|c|}
\hline \multirow{3}{*}{$\begin{array}{l}\text { Word } \\
\text { ending in } \\
\text { Japanese }\end{array}$} & \multicolumn{6}{|c|}{ Possible solutions and examples } \\
\hline & \multicolumn{2}{|l|}{ (1) } & \multicolumn{2}{|c|}{ (2) } & \multicolumn{2}{|l|}{ (3) } \\
\hline & $\begin{array}{l}\text { by morpholog- } \\
\text { ical rules; } \\
\text { singular }\end{array}$ & example & $\begin{array}{l}\text { plural } \\
\text { interpretation }\end{array}$ & example & $\begin{array}{l}\text { additional rules } \\
\text { and interpreta- } \\
\text { tions }\end{array}$ & example \\
\hline$-a$ & {$\left[\begin{array}{l}\text { f. sg. }<1> \\
{[+ \text { anim }]} \\
{[\text {-anim }]}\end{array}\right.$} & $\begin{array}{l}\text { gejša }-e \\
\text { ikebana }-e\end{array}$ & n. pl. <2> & - & 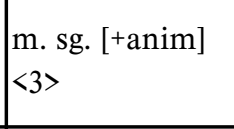 & jakuza -e \\
\hline$-e$ & m. sg. $(-j-)<4>$ & anime -ja & f. pl. $\langle 5\rangle$ & $\begin{array}{l}\text { karaoke } \\
\text { karaok } \\
\text { šitake šitak }\end{array}$ & $\begin{array}{l}\text { m. sg. }\langle 6\rangle \\
{[+ \text { anim }]}\end{array}$ & kamikaze-a \\
\hline$-i$ & m. sg. $(-\mathrm{j}-)<7\rangle$ & cunami -ja & m. pl. $\langle 8\rangle$ & - & $-V i>-V j$ m.sg. $\langle 9\rangle$ & samuraj-a \\
\hline$-O$ & m. sg. $(-j-)\langle 10\rangle$ & $g o-j a$ & & & m. sg. $\langle 11\rangle$ & kimono - $a$ \\
\hline$-u$ & m. sg. $(-j-)\langle 12\rangle$ & $t o f u-j a$ & & & & \\
\hline$-n$ & m. sg. $\langle 13\rangle$ & šogun - $a$ & & & & \\
\hline
\end{tabular}

\section{Words ending in - $a$}

$<1>$ The original Japanese nouns ending in $-a$ are interpreted as feminine nouns in the singular. The most typical examples are gejša $a^{10}$ 'geisha' and ikebana, both of which are already included in the Dictionary of Loanwords (Slovar tujk) published in 1968 (hereinafter ST 1968). Gejša fits well into Slovene since the word refers to a feminine person.

(8) Premiera opere o mladi gejši $\check{C}$ o Čo San bo v petek v veliki dvorani SNG.

[Dnevnik 2004-01-30]

»The first night of the opera about the young geisha Cio-Cio San will be on Friday in the large hall of SNG."

(9) Če po ulici postopate dalj časa, lahko srečate tudi gejše ... [Svet in ljudje 2003-10] »If you loaf about in the street for some time, you can meet geishas ..."

Other borrowings of this type with the meaning of masculine, not feminine, persons are classified under $\langle 3\rangle$ below.

10 Some Japanese consonants in loanwords are usually adapted to Slovene orthography according to their pronunciation: $s h / s y>\check{s}, j / z(y)>d \check{z}, c h / t(y)>\check{c}, t s / t>c, y / y>j$ (Japanese spelling in Hepburn system/Japanese spelling in kunrei system $>$ Slovene orthography, respectively). The vowel sequences $e i$ and $a i$ are often spelled as ej and $a j$ in Slovene. See Mlakar/Ilc (2009: 7-8) for details. This article focusses on gender and number assignment and does not go into detail regarding orthography. 
Ikebana originally means the art of flower arrangement and the definition in the Slovene dictionary remains the same, but the actual use shows that it is also used to denote individual pieces of arranged flowers or plants, thus used also in plural.

(10) $\check{S}$ tudij mode v Evropi je nadgradil s poglobitvijo v umetnost ikebane. [Mali svet 2004-12]

"He upgraded the study of fashion in Europe by delving into the art of ikebana."

(11) Izdelovali so različne ikebane in pripravljali novoletne piškote.

[Vestnik Murska Sobota 2006-08-17]

"They made different ikebanas and prepared New Year's cookies."

Among recent borrowings of this type are manga and tempura. Neither of the nouns is yet included in Slovene dictionaries. Manga is used in the singular to denote the genre, in the plural to denote individual examples of the publication, similar to the use of ikebana above.

(12) Japonski strip ali manga ima velikanski vpliv na japonsko bralno kulturo, ... [Mladina 1993-03-28]

"The Japanese comic strip or manga has great influence on the Japanese readership, ..."

(13) Na leto prodajo več kot milijardo in pol izvodov različnih mang. [Joker 2006-08-01]

"They sell more than a billion and a half copies of various mangas."

The word tempura, originally a method of preparing dishes, is used in Slovene in the same meaning but also means a certain kind of flour (example 14 below). Among examples found in the corpus, only one sentence was found in which the word was used in the plural (example 15 below).

(14) Repke škampov povaljamo v tempuro, zmešano z vodo, in jih ocvremo.

[Svet in ljudje 2003-10]

"We roll shrimp tails in tempura mixed with water, and fry them."

(15) ... saj je dnevno na voljo tako izbor tradicionalnih sušijev kakor sodobnejših suši kreacij, poleg sašimijev, tempur in nekaj izvirnih kreacij, ... [Playboy Slovenija 2003-04] "... a choice of traditional sushi is available daily, as well as modern sushi creations besides sashimi, tempura and some original creations, ..."

$<2>$ Theoretically, words ending in - $a$ may be understood as the plural form of neuter nouns, e.g. in Slovene besedilo besedila 'text, texts'. If the speakers feel comfortable with the solution, especially when the semantics of the word coincides with the plural connotation of countable objects, such an interpretation is possible. However, no such example was found. 
$<3>$ This is the interpretation of animate nouns ending in $-a$ and denoting persons, usually masculine. An additional Slovene rule applies, i.e. the second masculine inflection for nouns, of the type vojvoda -e 'duke' (Toporišič 2000: 288). If the borrowed words ending in $-a$ mean persons without additional specification for gender, they are systematically used as masculine nouns, e.g. jakuza 'yakuza', ninja/nindža. They are both included in the New Dictionary of Loanwords from 2002 (Veliki slovar tujk, hereinafter VST 2002).

(16) Japonska gangsterska organizacija jakuza služi denar z igrami na srečo, [2003-04-15]

"The Japanese gangster organization yakuza earns money by gambling, "

(17) Leta 1990 je bilo po nekaterih podatkih na Japonskem približno 87.000 poklicnih jakuzov, [Delo 2000-12-23]

"In 1990, according to some data, there were about 87,000 professional yakuzas in Japan, “

\section{Words ending in $-e$}

There are many Japanese words ending in $-e$ which have been borrowed into Slovene. The assignment of gender and number to these words is diverse. See $\langle 4\rangle$, $\langle 5\rangle$ and $\langle 6\rangle$ below.

$<4>$ The original Japanese words ending in $-e$ are interpreted as masculine nouns of foreign origin in the singular. Karate - $j a$ is a good example and has certainly been in use in Slovene since the 1960s, although it was not listed in neither of the dictionaries published in the 60s (Slovenski pravopis [Slovene Orthography] hereinafter SP 1962 and ST 1968), first appearing in the Dictionary of the Standard Slovene Language (SSKJ 1975). Of the same type is sake -ja (ST 1968). Karate denotes a martial art (or sport), sake denotes an alcoholic drink. Both are usually used in the singular.

(18) Trenutno se bolj izpopolnjuje $v$ karateju, [Nedeljski dnevnik 2000-11-05]

"At present, he is rather trying to improve at karate."

(19) Pokusili boste moj domači sake in .. [Dnevnik 2002-04-30]

"You will try my homemade sake, and..."

(20) Bil je proizvajalec sakeja (japonske nacionalne alkoholne pijače), [Mladina 1995-07-29]

"He was a manufacturer of sake (Japanese national alcoholic drink),"

$<5>$ Words ending in $-e$ are interpreted as feminine plural nouns of which the singular form may theoretically be traced back to words ending in $-a$. If the word is actually used also as a singular noun, the singular form is a new derivation in Slovene. Karaoke is 
defined as a plural noun in dictionaries, karaoke-ok (VST 2002 and SP 2007), and means the act of singing in a certain environment, i.e. with accompanying music. In practice, it is also used in the singular, as karaoka, a new derivation in Slovene (example 22).

(21) ...danes na karaokah prepevajo angleški gospodje srednjih let. [Delo 2002-10-12] "Nowadays English gentlemen of middle age are singing in karaoke."

(22) Karaoka je še vedno "en vogue», ... [Dnevnik 1998-06-17]

"Karaoke is still in vogue, ..."

There seems to be the same interpretation for nouns denoting an inanimate object, e.g. šiitake/ šitake "shiitake" (VST 2002). In this case, the word means a certain kind of mushroom, and in Slovene goba-e "mushroom" is also a feminine noun.

(23) O vzgoji shitak pa je več prispevkov napisal ravno predsednik prej navedenega društva. [Nedeljski dnevnik 1999-12-19]

"The president of the formerly mentioned association has written many articles on how to grow shiitake."

(24) Gobe šiitake k nam prihajajo z daljnega vzhoda, [Nedeljski dnevnik 2000-01-30]

"'Shiitake' mushrooms come to us from the Far East."

(25) Nekaj podobnega je bil rahlo eksotično obarvan krožnik s šitakami (japonskimi gobami), [Delo 2004-02-01]

"Something similar was the slightly exotic dish with shiitakes (Japanese mushrooms),"

(26) Potrebujemo (na osebo): $100 \mathrm{~g}$ piščančjega fileja, $40 \mathrm{~g}$ kumar, $40 \mathrm{~g}$ belega misa, $30 \mathrm{~g}$ gob šitaki, ... [Delo 2004-03-30]

"Ingredients (per person): $100 \mathrm{~g}$ chicken filet, $40 \mathrm{~g}$ cucumbers, $40 \mathrm{~g}$ white miso, $30 \mathrm{~g}$ 'shiitake' mushrooms, ..."

In the last example, "shiitake" is used as a masculine noun sitak $-i$. The female form in other examples, when pronounced, was perhaps mistaken for masculine, because the last vowel is not stressed (similar to $\langle 6\rangle$ below).

$<6>$ Words ending in $-e$ are interpreted as masculine singular nouns when the last vowel is considered as a non-voiced or unaccented $e$ after a consonant, as is the case for nouns from Latin or English (e.g. Wilde Wilda), though in Japanese all vowels in all syllables are fully voiced. For example, "kamikaze" in Japanese has the accent pattern of LHHH (with no accent core, or with no fall in the pitch within the word) but when borrowed into Slovene, a stress accent is placed on the third syllable, i.e. kamikáze (similarly in English /kami'ka:zi/ Oxford Dictionary of English 2002). Therefore, with the additional interpretation of the unaccented final vowel, some 
words ending in $-e$ are masculine (Toporišič 2000: 282). Semantically, kamikaze - $a$ (ST 1968) denotes a way of aircraft fighting, as well as a pilot of such an aircraft.

(27) Nekateri igralci so namreč kot kamikaze jurišali v nasprotne igralce.

[Delo 2001-01-22]

"For some players rushed at the enemy players like kamikaze."

(28) Kasai skače bolj tvegano, pogumen je kot kamikaza, [Dnevnik 1999-01-06]

"Kasai jumps more riskily, he is brave like a 'kamikaze'."

The word form in example (28) is a new creation. The original word is taken as a plural feminine form.

(29) V obdobjih neuspehov je Hillary Clinton moža reševala z odločnostjo kamikaz.

[Delo 1999-07-17]

"In times of failure Hillary Clinton rescued her husband with the decisiveness of a kamikaze."

(30) A zdaj se bo moral bojevati s kamikazami, kar zagotovo ne bo preprosto.

[Delo 2002-04-28]

"But now he has to fight with kamikazes, which will surely not be easy."

\section{Words ending in $-i$}

$<7>$ Original Japanese words ending in $-i$ are interpreted as masculine nouns of foreign origin in the singular. Examples are: kabuki -ja, kaki-ja (ST 1968) azuki -ja, cuna$m i-j a$, origami -ja (ST 2002). They are all regularly declined with the $-j-$ extension and used both in the singular and the plural. The recently very popular suši/sushi "sushi" should be included in this group, but it is not mentioned in any Slovene dictionary.

(31) Belo so se šminkali igralci kabukija, gejše in neveste. [Delo 2001-05-21]

"Kabuki actors, geishas and brides painted their faces white."

(32) Med njimi so bili tudi igralci gledališ̌a kabuki, [Delo 2000-12-15]

"Among them were actors of the kabuki theater."

(33) Poudarek je predvsem na sushiju, po katerem je japonska kuhinja tudi najbolj prepoznavna. [Besedilni drobiž 2006]

"The emphasis is above all on sushi, for which Japanese cooking is also the most known."

(34) Čez dan so na številnih stojnicah ponujali japonske dobrote, med katerimi so obiskovalci najpogosteje posegali po sušiju. [Delo 2003-05-18]

"During the day they offered Japanese food on many stalls among which the visitors most frequently reached for sushi." 
$<8>$ Theoretically, words ending in $-i$ may be understood as the plural of masculine nouns, e.g. in Slovene stol stoli 'chair, chairs'. However, no such example was found. $\langle 9\rangle$ When original Japanese nouns end in the vowel sequence -ai, Slovene orthography rewrites them to the diphthong -aj, probably because similar words with such word ending exist in Slovene, e.g. ležaj-a, papagaj - $a$ etc. The inflection follows the Slovene pattern, and because of $j$ at the end of the word the extension rule with an additional $j$ - for loanwords does not apply, but they are regularly inflected as masculine nouns. Examples are: samuraj-a (SP 1962) and bonsaj-a (VST 2002).

(35) Mi vsi smo svojevrstni samuraji. [GEA 2005-08]

"We are all samurais in our own way."

(36) Evropejci se za bonsaj ne odločimo vsak dan. [Nedeljski dnevnik 2000-02-06]

"We Europeans do not decide for bonsai everyday."

(37) Zgodovina bonsajev na Japonskem je nekaj stoletij krajša kot na Kitajskem,

[Nedeljski dnevnik 2000-02-06]

"The history of bonsais in Japan is some centuries shorter than in China."

\section{Words ending in -o}

$<10>$ Original Japanese words ending in - $o$ are interpreted as masculine nouns of foreign origin in the singular. If the last syllable carries the stress accent, the word should be declined as panó panója, if the accent falls on one of the previous vowels, the word should be declined as kino kina, without the extension with the additional $-j$. As we saw earlier, most of the Japanese syllables are open and all carry the same phonetic length. The fact is that among the words borrowed into Slovene and ending in the vowel $-o$, many have a long vowel -oo at the end of the noun in original Japanese (often written as ô, ō, or o:). Thus, originally, kendoo, budoo, and so on. These long vowels have been lost mainly due to transcription in European languages, and because the phonological system is different in the recipient language. One of the earliest borrowings, judo, as well as kendo and šinto all lost the long (or stressed) $-o$ and are now categorized under 11 below. ${ }^{11}$ The only word with this inflection is the one-syllable (and one-mora) word go -ja "go (Japanese board game)".

$<11>$ Original Japanese words ending in -o, without any distinction of whether or not the original word ends in a long or a short vowel, are declined after the pattern of Slovene words ending in -o, e.g. besedilo - $a$. Examples are: kimono - $a$, judo - $a$, šinto - $a$ (SP 1962, ST 1968), kendo $-a$ (ST 1968) and others.

(38) Kimoni so v deželi vzhajajočega sonca vedno manj priljubljeni, [Delo 2001-05-22]

"In the land of rising sun kimonos are less and less popular."

11 Mlakar/Ilc (2009: 9) proposes case inflection of masculine personal names with a long vowel $-\bar{o}$ with the -j- extension: Tarō Tarōja. 
(39) Srajca v stilu japonskega kimona je vedno modna. [Lisa 2004-09]

"A shirt in the style of a Japanese kimono is always fashionable."

(40) Tako je Udo Quellmalz v Atlanti osvojil zlato kolajno v judu. [Dnevnik 1997-02-10] "In this way, Udo Quellmalz won a gold medal in judo in Atlanta."

(41) sem mu omenil, da bi rad treniral judo. [Delo 2001-03-02]

"I told him that I would like to practice judo."

(42) so vatikanski teologi celo našli skupne točke z budizmom in šintom, [Mladina 2000] "Vatican theologians even found common points between Buddhism and Shinto."

(43) Danes je kendo tekmovalni šport in deluje po tekmovalnih pravilih. [Celjan 2001-10] "Today kendo is a competitive sport and functions by competitive rules."

\section{Words ending in $-u$}

$<12>$ Original Japanese words ending in $-u$ are interpreted as masculine nouns of foreign origin in the singular, e.g. tofú -ja, šiátsu -ja, zaibátsu -ja (VST 2002). They are regularly declined with the extension with $-j$-, as in kanu kanuja, even when the stress accent does not fall on the last syllable.

(44) Radič dobro operemo, ga razdelimo na liste in stresemo $k$ tofuju. [Delo 2004-02-17]

"We rinse the chicory well and divide it into small leaves which we add to the tofu."

(45) Torta z brokolijem in tofujem [Zdravje 2002]

"A pie with broccoli and tofu"

(46) To je nekakšna kombinacija japonskega šiacuja, kiropraktike, indijske joge in akupresure. [Delo 2000-01-12]

"This is some sort of a combination of Japanese shiatsu, chiropractics, Indian yoga and acupressure."

\section{Words ending in $-n$}

$<13>$ Original Japanese words ending in $-n$ are interpreted as masculine nouns in the singular. This case does not raise any problem since there are many Slovene nouns ending in the consonant $-n$ and they are usually masculine, e.g. balón, cigàn, bazén, račún. ${ }^{12}$ Loanwords of this type are šogun - $a$ (ST 1968), futon-a, zen - $a$ (VST 2002) etc.

(47) Doba šogunov se je končala 9. novembra 1867, [Dnevnik 2000-11-09]

"The era of shoguns ended on 9 November 1867."

12 In Slovene, nouns with a non-accented last syllable -en are feminine, e.g. básen basni "fable". 
(48) Poznamo tudi alternativne izvedbe vložkov, kot so futoni, slamnjače in rogoznice. [Dolenjski list 1998-05]

"We also know alternative realizations of cushions like futons, straw and reed mattresses."

(49) Po vsem svetu se zenu in zen meditaciji posveča vse večje število tistih,ki želijo...

[Mama 2005-03]

"All over the world there are more and more who devote themselves to Zen and Zen meditation..."

To summarise, the gender and number assignment occurs in the following order: according to the morphological form of the loanword, a gender of either masculine or feminine in singular is assigned. The semantics of animacy plays a big role in this process. If a loanword ends in $-a$ or $-e$ and means an animate being, particularly human and not specifically feminine, the semantics is stronger than the simple morphophonological rules and therefore the masculine gender is assigned. Phonology is also important in an additional two cases: the vowel sequences -ai and - $e i$ (orthographic change to $-a j$ and $-e j$ ), and the word ending - $o$ for words with two or more syllables (the rule for foreign words does not apply and there is no extension with additional $-j$-). These may be understood as 'naturalization' processes.

\section{LIMITS AND FURTHER CREATION}

Some of the loanwords are described as "indeclinable (neskl.)" in dictionaries. These are cases when the original forms of loanwords are such that inflection according to gender (and number) would make communication ineffective or impossible. For example:

(50) Predstavniki jamato-e so bili člani šole tosa, [Ft.Z.N.S.H humanistična in družboslovna] "The representatives of yamato-e were members of the Tosa school."

(51) Dela ukiyo-e so bila namenjena širokemu krogu porabnikov, [Dnevnik 2002-11-18] "The works of ukiyo-e were meant for a large audience."

Jamato-e/yamato-e and ukiyo-e (VST 2002) are Japanese art schools or styles. Though there has been much public interest in these genres of art in Slovenia, these words have not been completely integrated into the Slovene language system, including its orthography. The second part of the words ' $e$ ' means "picture", a one-syllable word, and this seems too short to undergo case inflection. In indeclinable cases, a similar or general naming of the same object or notion is used before the loanword to help communication:

(52) Ekstrakt iz gob šitake se je v laboratorijskih poskusih izkazal kot izjemno učinkovito sredstvo. [Delo 2001-05-11]

"In the lab experiments an extract from 'shiitake' mushrooms proved to be highly effective." 
Many nouns of Japanese origin have further derivations, mainly adjectives and nouns, in accordance with Slovene grammar. For example, the loanwords kamikaze, samuraj, judo, šogun, zen etc. have well-established derivations:

(53), saj smo se pogosto primorani na las natančno izogniti kakemu kamikaznemu kombiju [Joker 2006-08-01]

"We were often forced to somehow escape a kamikaze van by a hairs-breadth."

(54) starodavne borilne tehnike s samurajskim mečem. [Delo 2004-02-15]

"Ancient warring techniques with a samurai sword."

(55) Zenovsko-taoistični pogled na svet pa je pravzaprav tisto, [Večer 1999-05-10]

"The Zen-Taoistic view of the world is actually that of ..."

(56) $V$ sedmem stoletju je bil sumo pod vojskujočim se šogunskim režimom nekaj časa prepovedan [Gloss Slovenija 2004-07]

"In the $7^{\text {th }}$ century under the warring shogun regime, sumo was prohibited for some time."

(57) Futonska postelja, [Besedilni drobiz 2006]

"Futon bed,"

(58) Slovenski judoisti so se včeraj v beloruski metropoli udeležili zadnjega turnirja.

[Delo 1999-08-21]

"The Slovene judoists yesterday attended the last tournament in the Belarus capital."

Of course, nouns are used in many cases in the same nominative singular form in adjectival usage:

(59) Tisto, kar je v kabuki teatru trajanje, je v zahodnem dogajanje,

[Dnevnik 1999-07-30]

"Whatever is lasting in kabuki theater is action in the West."

(60) Tudi z majico s širokimi kimono rokavi in s prevezovanjem na ramenskem šivu boste zadeli v polno. [Nova 2003]

"Even with a shirt with wide kimono sleeves and knots on the shoulders you will shine."

\section{CREATIVE COMPETENCE}

With the loanwords of Japanese origin in Slovene, the following has been observed:

A. For the effective use of loanwords in communication, grammatical knowledge of the source language is not required. Such knowledge may even hinder free and creative competence in the recipient language. 
B. Foreign words are borrowed into the existing grammatical framework of the recipient language. Users of the recipient language find a proper place for each new word, if and only if they have a semantic reason for borrowing. If the environment in which a word may be received is free of possible misunderstanding and misinterpretation, all the existing rules apply. However, when the environment is 'crowded' with similar words and possible miscommunication, some additional mechanism is switched on, e.g. non-inflection, adjectival use of nouns, orthographic change etc., as seen and discussed above.

The most creative, and expressive, assignment of gender and number was observed with the plural noun karaoke. As discussed earlier, the possibility of plural assignment to a Japanese loanword of this type may occur if Slovene speakers recognize the denoted object as usually occurring in several pieces, e.g. siitake, or if the word is associated with plural proper nouns for places, e.g. Jesenice. (cf. Section 4.2, interpretation of (2) ) It seems that the word ending $-e$ in "karaoke" is associated with the latter case, for the connotation of "a place in which singing entertainment takes place'. As for proper nouns, the Japanese city of Kobe is sometimes analogically declined as a plural noun:

(61) Veliki potresi, film o potresu v Kobah l. 1995 [Dnevnik 2000-11-25]

"Major Earthquakes, a film about the earthquake in Kobe in 1995."

\section{CONCLUSION}

Due to the recent development of technology and rapid globalization, there are ever more foreign words and notions accepted in our everyday language use. Even Slovenia and Japan, two nations that are geographically and culturally very distant, are becoming closer. According to Wikipedia, there are more than 150 borrowed words of Japanese origin in Slovene. (Wikipedia: last modified: 7. October 2010) Based on the author's own judgement, some 60 of them (roughly 40\%) are generally known to all or most educated adult Slovene speakers and used regularly in today's Slovene.

This article does not cover the history of loanwords from Japanese into Slovene. The examples are not exhaustive and no statistical analysis on the use of loanwords has been carried out. Further research may disclose yet new facts and processes of borrowing from Japanese into Slovene.

\section{Bibliography}

Primary sources:

MLAKAR, Barbara/Iztok ILC (2009) "Predlogi za zapisovanje in pregibanje besed japonskega jezika." Azijske in afriške študije XIII-2: Predlogi za zapisovanje in pregibanje besed iz japonščine in kitajščine. Ljubljana: ZIFF, 3-14.

PRIESTLY, Tom M. S. (1993) “Slovene." In: B. Comrie/G. Corbett (eds), The Slavonic languages. London: Routledge, 388-451. 
SHIBATANI, Masayoshi (1990) "The Japanese Language 8: Phonology." The Languages of Japan. Cambridge: Cambridge University Press, 158-184.

TOPORIŠIČ, Jože (2000) Slovenska slovnica. Maribor: Založba Obzorja.

Corpus and references:

DOLESCHAL, Ursula/Anna M. THORNTON (eds) (2000) Extragrammatical and Marginal Morphology. München: Lincom Europa.

SHIGEMORI BUČAR, Chikako (ed.) (2009) Azijske in afriške študije XIII-2: Predlogi za zapisovanje in pregibanje besed iz japonščine in kitajščine. Ljubljana: ZIFF.

SHIGEMORI BUČAR, Chikako (2009) "Surobeniago (Slovenian).” In: S. Kaji, Y. Nakajima, T. Hayashi (eds) Jiten Sekai no Kotoba 141. Tokyo: Taishukan, 322-325. [COBISS.SI-ID 39597666]

ZWICKY, Arnold M./Geofrey K. PULLUM (1987) "Plain morphology and expressive morphology." In: J. Aske et al. (eds), Proceedings of the Thirteenth Annual Meeting of the Berkeley Linguistic Society. Berkeley: Berkeley Linguistic Society, 330-340.

Slovenski pravopis SAZU. BAJEC, Anton et al. (1962). Ljubljana: Državna založba Slovenije. [SP 1962]

Slovar tujk. VERBINC, France (1968). Ljubljana: Cankarjeva založba. [ST 1968]

Slovar slovenskega knjižnega jezika. (\{1970, 1975, 1979, 1985, 1991]1995). Ljubljana: Inštitut za slovenski jezik Frana Ramovša ZRC SAZU [SSKJ]

Veliki slovar tujk. TAVZES, Miloš (ed) (2002). Ljubljana: Cankarjeva založba. [VST 2002]

Slovenski pravopis. TOPORIŠIČ, Jože et al. (eds) (2007). Ljubljana: SAZU/ZRC SAZU. [SP 2007]

Oxford Dictionary of English (2003). Oxford: Oxford University Press.

Fidaplus. 10 July 2011. http://www.fidaplus.net/

Wikipedia: Seznam slovenskih besed japonskega izvora. 10 July 2011.

http://sl.wikipedia.org/wiki/Seznam_slovenskih_besed_japonskega_izvora

$\begin{array}{ll}\text { List of abbreviations: } \\ \text { ACC } & \text { accusative case } \\ \text { C } & \text { consonant } \\ \text { CONT } & \text { continuous verb form } \\ \text { DAT } & \text { dative case } \\ \text { f. } & \text { feminine } \\ \text { GEN } & \text { genitive case } \\ \text { H } & \text { high tone } \\ \text { INST } & \text { instrumental case } \\ \text { L } & \text { low tone } \\ \text { LOC } & \text { locative case } \\ \text { m. } & \text { masculine } \\ \text { n. } & \text { neuter } \\ \text { NOM } & \text { nominative case }\end{array}$




$\begin{array}{ll}\text { pl. } & \text { plural } \\ \text { PRES } & \text { present tense } \\ \text { sg. } & \text { singular } \\ \text { V } & \text { vowel }\end{array}$

\section{Abstract \\ CREATIVE COMPETENCE IN BORROWINGS: WORDS OF JAPANESE ORIGIN IN SLOVENE}

Japanese has no category of gender or number. Nouns as well as adjectives have no inflection. The phonological construction of words is syllabic and there is no stress accent but pitch accent. Five vowels have short and long opposition. On the other hand, Slovene has categories of number and gender. Nouns are inflected according to six cases. Phonologically, all nouns carry a stress accent. In this paper, the gender and number assignment to loanwords of Japanese origin in Slovene is discussed on the basis of the morphology and phonology of the source and recipient languages. Assignment rules have certain morphological and semantic foundations. The relative competence of the speakers of the recipient language, Slovene, is particularly noticeable when activating the categories and rules that are specific to their own language. The integration of loanwords may be observed through the additional derivation of adjectives and nouns within the framework of the recipient language.

\section{Povzetek \\ USTVARJALNA KOMPETENCA V IZPOSOJANJU: BESEDE JAPONSKEGA IZVORA V SLOVENŠČINI}

Japonščina nima slovničnih kategorij spola in števila. Samostalniki in pridevniki se ne sklanjajo. Besede so sestavljene z odprtimi zlogi s tonemskim, ne z jakostnim naglasom. Vsi japonski samoglasniki imajo kratko in dolgo različico. Na drugi strani pozna slovenščina kategoriji števila in spola. Oblike samostalnikov se spreminjajo glede na število, spol in sklon. Vsi samostalniki nosijo jakostni naglas.

Pričujoči prispevek obravnava glede na oblikoslovne in fonološke značilnosti obeh jezikov določanje spola in števila pri sprejemanju izposojenk iz japonščine v slovenščino. Pravila pri določanju spola in števila temeljijo na oblikoslovju in semantiki: za število ima prednost nezaznamovana različica, ednina, za spol moški ali ženski spol glede na samoglasnik (le izjemoma soglasnik) zadnjega zloga prvotne japonske besede. Jezikovno ustvarjalna sposobnost govorcev jezika prejemnika, slovenščine, je zlasti opazna, kadar se upoštevajo kategorije in pravila, ki so specifično slovenski. Semantika vršilca oz. udeleženca kot živega bitja ima pomembno vlogo pri določanju spola, ravno tako tudi množinskost samostalnika, če to dovoljuje oz. pričakuje sobesedilo, v katerem se nova beseda uporablja (npr. karaoke, šitake). Popolno integracijo izposojenk prepoznamo pri izpeljavi pridevnikov in dodatnih samostalnikov, ki so nove tvorbe znotraj jezika prejemnika (npr. kamikazni kombi, samirajski meč, judoist). Najbolj izvirno določanje spola in števila je opazno pri samostalniku karaoke. 